\title{
PENGGUNAAN GOOGLE CLASSROOM DI KELAS VIRTUAL DALAM PEMBELAJARAN BAHASA INDONESIA PADA MASA PANDEMI COVID-19
}

\author{
Berlyana Rahmawati, Haryanti Budhi Utami, Benedictus Sudiyana, \\ Agus Rohadi \\ Universitas Veteran Bangun Nusantara Sukoharjo \\ Email: berlyanarahmawati5414@gmail.com
}

\begin{abstract}
Abstrak: Adanya pandemi covid-19 sejak akhir tahun 2019 berpengaruh terhadap proses pembelajaran, yaitu tidak memungkinkan diadakannya pembelajaran dengan sistem tatap muka di kelas. Sesuai kebijakan pemerintah, pembelajaran formal di sekolah harus dilaksanakan secara daring dan salah satu medianya adalah aplikasi google classroom. Wahana tersebut merupakan hal baru bagi siswa sehingga memungkinkan berbagai hambatan dalam penggunaannya. Penelitian ini bertujuan untuk mendeskripsikan implementasi google classroom sebagai pengembangan kelas virtual dalam pembelajaran Bahasa Indonesia pada masa pandemi covid-19. Metode penelitian ini adalah kualitatif deskriptif dengan melalui observasi langsung di SMA Negeri 1 Polokarto, Kabupaten Sukoharjo. Hasil penelitian menunjukkan bahwa pemanfaatan aplikasi google classroom dalam pembelajaran sudah efektif. Aplikasi dapat dioperasikan guru dan siswa. Meskipun demikian, siswa masih membutuhkan bimbingan guru secara langsung atau tatap muka selain pembelajaran daring melalui google classroom.
\end{abstract}

Kata Kunci : google classroom, kelas virtual, Bahasa Indonesia, covid-19

\section{USING GOOGLE CLASSROOM AS A VIRTUAL CLASS FOR LEARNING INDONESIAN LANGUAGE IN THE COVID-19 PANDEMIC TIME}

\begin{abstract}
The existence of the Covid-19 pandemic since the end of 2019 has affected the learning process, which is not allowing face-to-face learning in classrooms. According to government policy, formal learning in schools must be carried out online and one of the media is the google classroom application. This vehicle is a new thing for students so that it allows various obstacles in its use. This research aims to describe the implementation of the google classroom as the development of a virtual classroom in Indonesian language learning during the Covid-19 pandemic. This research method is descriptive qualitative through direct observation at SMA Negeri 1 Polokarto, Sukoharjo Regency. The results showed that the use of the google classroom application in learning was effective. Applications can be operated by teachers and students. Even so, students still need direct or face-to-face teacher guidance in addition to online learning through google classrooms.
\end{abstract}

Keywords: google classroom, virtual class, covid-19

BASASTRA Jurnal Bahasa, Sastra,dan Pengajarannya

Volume 9 Nomor 1, April 2021, P-ISSN 2302-6405, E-ISSN 2714-9765 


\section{PENDAHULUAN}

Wabah corona virus disease 2019 (covid-19) yang telah menyerang 215 negara di dunia, tentu menjadikan tantangan tersendiri bagi lembaga pendidikan, khususnya Perguruan Tinggi. Cara yang dilakukan untuk melawan Covid-19, pemerintah telah melarang keras masyarakat dalam berkerumun, pembatasan sosial (social distancing) dan menjaga jarak fisik (physical distancing), memakai masker dan selalu cuci tangan. Covid19 adalah virus yang mudah menular tanpa gejala. Sebagain besar yang terkena virus tersebut merasakan pernapasan ringan dan dalam proses penyembuhan tanpa perawatan khusus. Semenjak pertama kali virus corona terdeteksi di Wuhan, China, pada Desember 2019, wabah ini sudah berkembang dengan pesat. Gejala khas Covid-19 termasuk merasakan demam, kesulitan bernapas, dan batuk. Wabah tersebut lebih parahnya, virus ini dapat mengganggu pernapasan, syok septik dan lain sebagainya. Kita bisa mengurangi penyebaran dengan mengikuti protokol yang ada atau menggunakan masker, mencuci tangan, menjaga jarak (3M). (Umairah, 2020)

Melalui Kementerian Pendidikan dan Kebudayaan Pemerintah telah melarang sekolah untuk melaksanakan pembelajaran tatap muka (konvensional) dan memerintahkan untuk menyelenggarakan perkuliahan atau pembelajaran secara daring (Surat
Edaran Kemendikbud Dikti Nomor 1 tahun 2020). Perguruan tinggi dituntut untuk dapat menyelenggarakan pembelajaran secara daring atau online (Setiawan, Puspaningrum, \& Umam, 2019).

Bahasa Indonesia adalah salah satu mata pelajaran yang wajib ada di sekolah dasar sampai dengan perguruan tinggi. Ragam yang nantinya dipelajari oleh siswa ketika mereka akan melanjutkan sekolah ke jenjang yang lebih tinggi lagi. Dengan hal tersebut dasar pembelajaran Bahasa Indonesia sangat penting untuk menjadi perhatian guru dan siswa. Berdasarkan hasil observasi yang dilakukan, banyak siswa yang mengeluh bosan dengan media pembelajaran yang digunakan oleh gurunya terutama di SMA Negeri 1 Polokarto. Hal ini tentu menjadi perhatian besar, mengingat motivasi belajar merupakan hal terpenting dalam mendukung kesuksesan pembelajaran yang dilakukan oleh guru. Motivasi merupakan suasana yang dapat mendorong seseorang untuk melakukan atau mengerjakan sesuatu. Dalam bidang pendidikan motivasi tentunya berorientasi pada pencapaian kondisi yang mendorong siswa untuk dijadikan semangat dalam kegiatan belajarnya (Oktiani, 2017).

Dalam pembelajaran daring siswa belajar dengan cara mengikuti keterlibatan secara aktif baik itu dalam tugas sehari-hari maupun tugas lainnya. Untuk itu pihak sekolah 
sebagai pihak yang sangat berpengaruh terhadap pendidikan siswa wajib mengarahkan penggunaan smartphone dengan baik. Berkembangnya teknologi smartphone saat ini merupakan benda yang sudah dimiliki semua orang dan terlalu banyak tipe-tipenya, aplikasi dalam smartphone yang disebut Google Classroom atau Google Kelas. Aplikasi tersebut juga bisa digunakan di berbagai tipe smartphone. Untuk melakukan kelas siaran langsung, tugas daring, dan untuk menampilkan materi bisa melalui Google Meet. Namun jika menggunakan Google Meet memberatkan siswa karena menggunakan kuota yang banyak belum lagi masih banyak daerah tidak ada sinyal. Agar tidak memberatkan siswa guru pembelajaran Bahasa Indonesia menggunakan Google Classroom karena lebih simpel dan tidak memerlukan kuota yang terlalu memberatkan siswa. Google Classroom adalah alat untuk membantu proses pembelajaran guru dengan siswa untuk menyampaikan materi atau tugas secara daring.

Pembelajaran daring memiliki tujuan untuk memberikan layanan yang bersifat masif dan lebih umum agar peminatnya lebih banyak (Oktafia, 2020). WFH yaitu singkat dari work from home yang artinya bekerja dari rumah. Sebagai ASN, guru dalam melaksanakan proses pembelajaran perlu dilakukan secara dalam jaringan (daring) selama pandemi ini berlangsung. Namun, dengan adanya pelaksanaan proses pembelajaran secara daring memiliki banyak kendala. Salah satu kendala terberat dalam pembelajaran daring yaitu mengajar mata pelajaran Bahasa Indonesia. Jenis media daring dalam pembelajaran daring yang digunakan seperti youtube, grup whatsapp, zoom dan google classroom. Materi yang diberikan oleh siswa dalam bentuk power point, video singkat, dan bahan bacaan. Hal itulah yang mendasari penulis untuk mengetahui gambaran keefektifan pembelajaran daring menggunakan media online pada mata pelajaran Bahasa Indonesia. (Umairah, 2020).

Berdasarkan observasi lapangan peneliti di masa pandemi covid-19 ini dalam proses pembelajaran dengan melalui aplikasi Google Classroom terhadap siswa kelas X di SMA Negeri 1 Polokarto, sebagian siswa mengatakan bahwa sebagian siswa merasa bosan terhadap kelas virtual tanpa bertatap muka langsung dengan guru. Bahkan dalam mengerjakan tugas sebagian siswa juga tidak mengumpulkan dengan alasan lupa. Dengan alasan-alasan yang sudah disebutkan di atas maka diperlukan adanya suatu media pembelajaran Bahasa Indonesia yang dapat memungkinkan siswa agar merasa nyaman ketika pembelajaran berlangsung dan bisa aktif dalam mengonstruksi pengetahuannya kapan saja dan di mana saja tanpa dibatasi 
ruang maupun waktu. Rumusan masalah dalam penelitian ini yaitu bagaimanakah perkembangan belajar siswa dalam pembelajaran Bahasa Indonesia melalui Google Classroom?

Pada saat ini pembelajaran yang terpusat pada guru tidak terlalu cocok pada generasi milenial seperti sekarang ini, sehingga perlu banyak perubaham ke pendekatan yang lebih berpusat pada siswa yang berbedabeda kemampuannya (Maharani \& Kartini, 2019). Sampai saat ini aplikasi Google Classroom memang sudah digunakan dalam pembelajaran di dunia barat sebagai penunjang dalam kegiatan pembelajaran dan suatu bentuk penyemangat terhadap kemajuan teknologi saat ini. Pengaplikasian Google Classroom sangat mudah dipakai untuk kegiatan pembelajaran bahkan pada tahun 2017 Google Classroom bisa diakses oleh semua orang melalui google pribadi. Aplikasi Google Classroom ini dapat diunduh secara gratis di perangkat berbasis android maupun iOS.

Oleh karena itu, ditetapkan pengumuman dari pemerintah mengenai adanya larangan untuk ke sekolah dan tatap muka proses pembelajaran di berbagai jenjang pendidikan. Sehingga siswa harus menggunakan pembelajaran dengan metode daring agar pembelajaran tetap berlanjut meskipun dengan adanya banyak kendala. Siswa yang belajar dari rumah harus menggunakan aplikasi tertentu yang ditentukan oleh guru. Penelitian ini bertujuan untuk mendeskripsikan penggunaan Google Classroom sebagai pengembangan kelas virtual dalam pembelajaran Bahasa Indonesia di masa pandemi covid-19.

\section{METODE}

Jenis penelitian yang digunakan yaitu penelitian deskriptif kualitatif dengan pendekatan studi kasus. Penelitian dilakukan dengan cara observasi secara langsung dan melakukan wawancara terhadap beberapa siswa melalui aplikasi WhatsApp. Tujuan penelitian ini adalah mengetahui pengembangan kelas virtual yang dilakukan di kelas 10. SMA Negeri 1 Polokarto. Pembelajaran daring yang dimaksud dalam penelitian ini yaitu pembelajaran yang menggunakan suatu media-media pembelajaran yang dapat diakses menggunakan layanan internet.

Subjek penelitian di sini adalah siswa kelas X SMA Negeri 1 Polokarto yang telah melaksanakan pembelajaran daring, dan dibuat kelompok melalui tanggapan subjek penelitian. Didapatkan 8 orang subjek penelitian, 4 orang siswa jurusan MIPA dan 4 orang siswa dengan jurusan IPS. Pengumpulan data dilakukan melalui wawancara via WhatsApp. Hal-hal yang ditanyakan dalam wawancara tersebut adalah: (1) kondisi awal pembelajaran di kelas virtual; (2) kondisi pembelajaran 
setelah siswa mampu mengoperasikan aplikasi google classroom; keefektifan pembelajaran daring; (4) solusi terhadap kendala kelas virtual dengan Google Classroom.

Penelitian dilakukan dengan terlebih dahulu dengan melakukan survei kepada siswa mengenai penerapan kelas virtual. Survei dibuat melalui google form yang diberikan kepada siswa melalui pesan grup di WhatsApp. Ada 96 orang subjek yang telah memberikan respon terhadap survei yang disebarkan. Hasil survei kemudian dikelompokkan ke dalam tiga kategori respon siswa: (1) Setujukah dengan penerapan pembelajaran daring; (2) Tidak setuju dengan penerapan pembelajaran daring; (3) Ragu dengan pelaksanaan pembelajaran daring. Analisis data penelitian dilakukan menggunakan model analisis interaktif (yang terdiri dari tiga tahapan, yaitu reduksi data, display data, serta penarikan dan verifikasi kesimpulan.

\section{HASIL DAN PEMBAHASAN}

\section{Kesulitan Pengoperasian Google Classroom pada Awal Pembelajaran}

Sebagai pengalaman yang baru, pengaplikasian google classroom dilatihkan kepada siswa kelas X SMA Negeri 1 Polokarto sebelum dilakukan pembelajaran di kelas virtual. Latihan dilakukan secara mandiri melalui pemberian petunjuk lewat WhatsApp Group kelas. Berdasarkan petunjuk tersebut satu hari sebelum dimulai pembelajaran, siswa diminta berlatih dan jika mengalami kesulitan bisa menelepon guru wali kelas. Selama latihan ada beberapa siswa yang menghubungi wali kelas masingmasing dan setelah diberi penjelasan, mereka menyatakan sudah memahami cara pengoperasian google classroom.

Berdasarkan hasil observasi pada awal pelaksanaan pembelajaran di kelas virtual, sebagian besar siswa mengalami kesulitan dan kendala dalam menerapkan langkah-langkah untuk memecahkan masalah. Siswa mengemukakan bahwa mereka tidak bisa berkonsentrasi sehingga tidak memperhatikan materi yang diajarkan guru. Hal itu disebabkan terjadinya kesalahan-kesalahannya dalam mengoperasikan aplikasi google classroom. Hal itu dapat dikaitkan dengan pernyataan siswa di bawah ini.

"Saya tidak dapat konsentrasi dalam pembelajaran karena beberapa kali salah meng-klik sistem yang ada di aplikasi google classroom." (Data 1)

"Pada pembelajaran online, saya kesulitan mengoperasikan aplikasi google classroom karena baru kali ini menggunakannya sehingga tidak bisa fokus dalam pelajaran". (Data 4).

"Aplikasi untuk pembelajaran daring ini rumit, saya sudah mengikuti panduan, tetapi masih kesulitan. Jadinya tidak nyaman belajarnya." (Data 7) 
Selain kesulitan berkonsentrasi dalam memahami materi pelajaran, adanya kesulitan mengoperasikan aplikasi google classroom juga mengakibatkan para siswa tidak tertarik dan tidak termotivasi belajar Bahasa Indonesia. Selain itu, siswa juga mengemukakan bahwa keterampilan pemecahan masalah yang dimilikinya dirasakan sangat kurang sehingga siswa sulit untuk terampil dalam mengerjakan tugas yang diberikan. Simpulan tersebut dapat dilihat dari pernyataan beberapa siswa berikut ini.

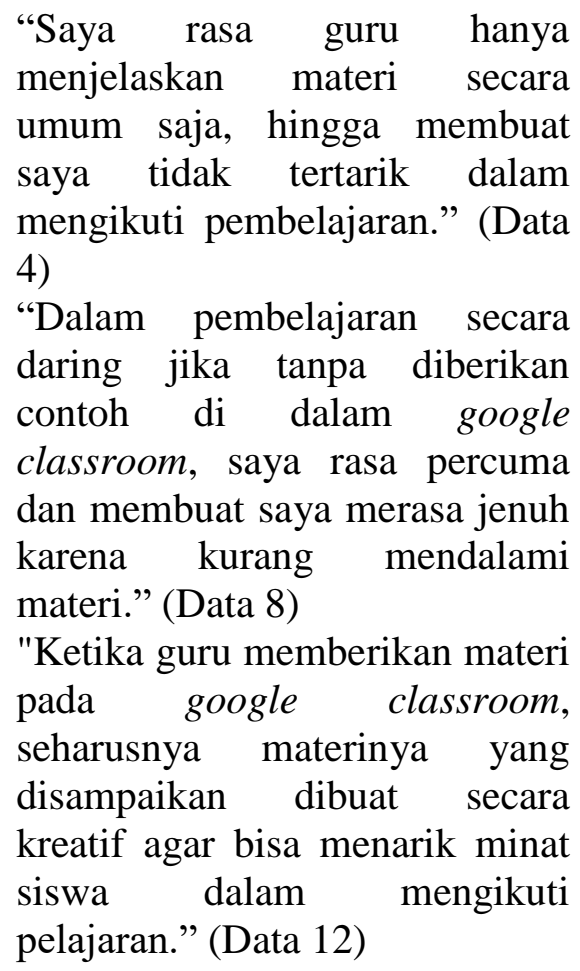

\section{Peningkatan Kompetensi dan Motivasi Siswa}

Pada minggu kedua, siswa mulai dapat menggunakan aplikasi google classroom sehingga mereka dapat berkonsentrasi selama pembelajaran.
Mereka tidak hanya dapat menyimak penyampaian materi yang diberikan guru, tetapi juga dapat mengaktifkan fitur-fitur untuk memberikan respon guru. Hal tersebut membuat siswa termotivasi dalam mengikuti pembelajaran. Hal itu dapat dikaitkan dengan pernyataan beberapa siswa di bawah ini.

"Ternyata tidak terlalu sulit menggunakan google classroom bahkan setelah bisa memakai google classroom, saya bisa mengoperasikan sarana yang tersedia. Itu membuat saya lebih suka pembelajaran dengan aplikasi itu daripada melalui WhatsApp seperti mingguminggu sebelumnya." (Data 9) "Pada awalnya saya agak lupa untuk membuka aplikasi google classroom, tetapi setelah membuka catatan, saya bisa menggunakannnya.

Alhamdulillah saya bisa mengikuti pembelajaran, termasuk cara melakukan share screen, membuat screen shoot. Hal yang baru itu membuat semangat belajar tumbuh lagi." (Data 11).

"Setelah berlatih dan bertanya kepada guru wali kelas dan teman, saya tidak lagi kesulitan memanfaatkan semua fitur yang ada sehingga jadi semangat untuk sekolah. Saya sudah bisa menayangkan power point untuk presentasi kelompok." (Data 14) 
Tantangan yang Dihadapi Siswa dalam Pembelajaran di Kelas Virtual

Tantangan pertama dalam pembelajaran melalui daring adalah ketersediaan layanan internet. Kebanyakan dari siswa mengakses internet dengan menggunakan layanan selular, dan sebagian kecilnya menggunakan layanan WiFi. Adapun beberapa siswa yang mengeluh mengalami kesulitan sinyal karena sering mengalami gangguan jaringan maupun tempat tinggal siswa masih dibilang berada di desa yang pelosok, jikapun ada sinyal yang bisa digunakan untuk mengakses namun sangatlah lemah. Hal tersebut menjadi tantangan tersendiri dalam penerapan pembelajaran kelas virtual di SMA Negeri 1 Polokarto terutama kelas X. Hal itu dapat dikaitkan dengan pernyataan siswa sebagai berikut ini.

"Dengan menggunakan aplikasi google classroom dengan sinyal di rumah yang begitu rendah membuat saya harus mencari sinyal di tempat yang lebih tinggi di luar rumah. Karena itu saya tidak bisa mencatat hal penting dalam pelajaran." (Data 6)

"Jika pandemi tidak segera pergi, saya rasa dengan jaringan yang susah selama pembelajaran saya tidak akan tahu apa-apa mengenai materi. Gangguan sinyal membuat saya terlempar keluar dari kelas virtual sehingga saya tidak bisa mengikuti pelajaran secara utuh." (Data 11)
"Sinyal di rumah saya tidak baik karena letak rumah saya di balik bukit. Agar bisa mengikuti pembelajaran pada google classroom, saya harus mengungsi ke rumah teman agar tidak ketinggalan mengikuti pembelajaran." (Data 15)

Selain yang berkaitan dengan sinyal internet, tantangan lain yang dihadapi siswa adalah terbatasnya waktu pembelajaran, yaitu tidak sepanjang pembelajaran di sekolah sebelum pandemi. Keterbatasan waktu itulah yang membuat guru terlalu cepat menjelaskan materi dan hanya beberapa siswa yang memungkinkan untuk bertanya. Oleh karena itu, siswa menyatakan berharap ada bimbingan khusus atau tambahan waktu di luar pembelajaran di kelas virtual. Fenomena tersebut dapat dilihat dari pernyataan beberapa siswa sebagai berikut ini.

"Kekurangan pembelajaran di kelas virtual adalah waktunya yang lebih singkat dibandingkan di kelas normal. Maka guru yang menjelaskan materi agak cepat sehingga saya ketinggalan ketika mencatat." (Data 6).

"Karena waktu pembelajaran daring lebih pendek, waktu untuk presentasi kelompok juga terbatas. Hal itu membuat pembelajaran kurang efektif. Saya kadang tidak punya kesempatan untuk bertanya kepada guru. Makanya saya harap guru membuatkan ringkasan materi pelajaran." (Data 14). 
"Kalau pembelajaran Bahasa Indonesia hanya dilakukan di kelas daring, sepertinya banyak materi yang belum dipahami, misalnya menulis karena biasanya kalau di kelas regular guru menunjukkan contoh." (Data 15)

Tantangan lain yang terjadi adalah adanya sebagian siswa yang tidak aktif mengikuti pembelajaran. Hal itu disebabkan siswa tahu bahwa guru tidak dapat memantau kehadiran dan keaktifan siswa sepanjang waktu pembelajaran. Beberapa pernyataan siswa di bawah ini menunjukkan hal itu.

"Belajar melalui daring, menurut saya bisa santai tidak seperti di kelas luring karena guru tidak bisa mengawasi setiap siswa. Kadang saya mematikan video sebentar kalau ingin istirahat." (Data 10)

"Karena pembelajaran dilakukan dari rumah masing-masing siswa, seringnya orang tua mengira sekolahnya tidak serius makanya pas pelajaran mereka menyuruh anaknya untuk ikut membantu melakukan pekerjaan rumah seperti memberi makan ternak. Untuk itu siswa terpaksa meninggalkan kelas virtual." (Data 14)

Walaupun penggunaan smartphone mendukung dalam pembelajaran daring, namun juga ada dampak negatifnya perlu mendapat perhatian yaitu penggunaan smartphone yang berlebihan menyebabkan gangguan mata, duduk di depan komputer/laptop berjam-jam, kurangnya aktivitas gerak, tidak dapat mengukur indikator ketercapaian pembelajaran siswa. Selain untuk pembelajaran siswa mengakui juga untuk main game, media sosial dan juga YouTube. Siswa menggunakan media sosial untuk mengakses internet, jejaring pertemanan dan informasi yang lebih luas.

Tantangan yang lain bahwa kendala biaya pembelajaran daring. Siswa mengeluhkan jika mengikuti pembelajaran daring memerlukan biaya yang cukup banyak untuk membeli kuota internet. Menurut siswa, pembelajaran dalam bentuk video dari WhatsApp atau dari YouTube telah menghabiskan banyak kuota data.

\section{Keefektifan Pembelajaran Daring}

Dengan makin mahirnya siswa dalam mengoperasikan aplikasi google classroom selain menjadikan siswa semangat belajar, juga memungkinkan siswa dapat mengerjakan tugas dari guru dengan baik. Nilai sebagian besar siswa juga dapat mencapai KKM pada materi pelajaran Bahasa Indonesia. Kebanyakan dari siswa mengatakan bahwa dengan adanya kelas virtual, siswa merasa puas karena menurut mereka pembelajarannya fleksibel. Dengan pembelajaran kelas virtual, guru dapat memberikan pembelajaran melalui Google Classroom yang bisa diakses kapan saja. Kondisi tersebut membuat siswa dapat secara bebas 
memilih mata pelajaran yang dikuti dan tugas mana yang harus dikerjakan terlebih dahulu. Hal itu dapat dikaitkan dengan pernyataan beberapa siswa di bawah ini.

"Setelah mempelajari secara sungguh-sungguh aplikasi google classroom dan belatih bersama teman-teman, akhirnya saya dapat mengoperasikan sistemnya dengan baik ketika mengirim tugas." (Data 8).

"Pada pembelajaran online ini, akhirnya saya bisa konsentrasi saat mengikuti pembelajaran dan bisa mengerjakan tugas ketika membaca materi yang sudah diberikan oleh guru melalui google classroom." (Data 19)

"Setelah mengetahui cara-cara mengirim tugas pada google classroom, akhirnya saya bisa nyaman dan tidak bingung lagi bertanya-tanya dengan teman yang lain." (Data 21)

Berdasarkan uraian di atas, hasil penelitian dapat disimpulkan bahwa pada awal pembelajaran siswa masih mengalami kesulitan untuk mengoperasikan aplikasi google classroom. Temuan tersebut sejalan dengan hasil penelitian Amalia, Bekti Isnaeni, dkk (2020). Akan tetapi, setelah berlatih dan mempraktikkan petunjuk dari guru wali kelas serta berlatih bersama teman, siswa mulai mampu memanfaatkan fitur-fitur yang ada dalam pembelajaran. Adapun yang menjadi kendala bagi siswa dalam pembelajaran daring dengan aplikasi google classroom adalah sinyal di tempat tinggal sebagian siswa yang tidak baik sehingga mengganggu kelancaran dalam belajar.

Tantangan dalam pembelajaran daring adalah ketersediaan layanan internet dan jaringan internet. Hal ini sejalan dengan hasil penelitian Herliandry, Nurhasanah, Suban, dkk. (2020). Pembelajaran daring tidak bisa jauh dari jaringan dan kuota internet. Koneksi jaringan internet menjadi satu-satunya kendala yang harus dihadapi siswa yang tempat tinggalnya sulit untuk mengakses internet, apalagi siswa tersebut tempat tinggalnya masih di daerah pedesaan dan terpencil. Jikapun ada yang menggunakan jaringan seluler terkadang jaringan yang tidak stabil dan harus menunggu lama ketika mengakses, karena letak geografis yang masih jauh dari jangkauan sinyal seluler. Hal ini juga menjadi permasalahan yang banyak terjadi pada siswa yang mengikuti pembelajaran daring sehingga kurang optimal pelaksanaannya.

Dalam pembelajaran daring siswa bisa langsung mengikuti proses belajar dari rumah. Penggunaan pembelajaran daring dengan media google classroom seperti yang diterapkan di SMA Negeri 1 Polokarto memiliki kelebihan berinteraksi langsung siswa dan guru. Namun juga memilih kelemahan yaitu menjadikan malas siswa untuk melakukan belajar bahkan mengikuti zoom tanpa memperlihatkan diri. Tentu hal itu dilakukan untuk presensi semata. 
Selain itu, juga boros kuota dan kurang efektif. Belum lagi siswa tidak tahu tentang materi dan tugas yang diberikan guru.

Sebagian siswa dengan adanya pembelajaran daring dapat mengakses menggunakan layanan seluler dan sebagian menggunakan WiFi. Apabila kebijakan pembelajaran daring, siswa mengalami kesulitan sinyal di daerahnya masing-masing, jika ada sinyal yang didapatkan lemah. Hal ini menjadikan tantangan untuk seorang guru menghadapi pembelajaran daring karena adanya Covid-19. Kendala ini sama dengan temuan Hutauruk \& Sidabutar (2021) bahwa para mahasiswa pun mengalami kendala sinyal dalam pembelajaran daring.

Berdasarkan pendapat para siswa serta guru Bahasa Indonesia dapat disimpulkan kegiatan belajar tatap muka dengan guru lebih efektif daripada secara daring (online), termasuk dengan menggunakan google classroom. Beberapa guru di sekolah mengatakan, jika pembelajaran daring ini tidak seefektif kegiatan pembelajaran konvensional (tatap muka langsung), karena beberapa materi harus dijelaskan secara langsung dan lebih lengkap. Dengan hal itu siswa juga bisa dengan mudah menangkap materi yang disampaikan oleh guru. Selain itu, materi yang disampaikan secara daring belum tentu bisa dipahami semua siswa. Banyak siswa merasa bosan dan bermalasmalasan mengikuti pembelajaran bahkan memilih tidak ikut pelajaran yang dilakukan. Berdasarkan pengalaman mengajar secara daring, sistem ini hanya efektif untuk memberi tugas dan memberikan materi ketika guru tidak bisa datang ke sekolah.

\section{SIMPULAN}

Pembelajaran daring SMA Negeri 1 Polokarto berjalan dengan baik dan efektif karena dapat menyelesaikan materi yang belum tersampaikan oleh guru dengan kendala umum yaitu masalah sinyal dan kuota yang mahal. Jadi, dapat disimpulkan bahwa dalam pembelajaran pada masa pandemi saat ini, posisi guru dalam memberikan bimbingan dan tambahan materi tertulis masih sangat penting bagi siswa dibandingkan melalui aplikasi secara daring.

\section{REFERENSI}

Amalia, R.U., Isnaeni, B., Purwati \& Hanafi, Y. (2020). Analisis Kendala Peserta Didik dalam Pembelajaran Online Materi Biologi di SMP Negeri 3 Bantul. Jurnal Bio Educatio, 5 (2), 1015.

Handayani, L. (2020). Keuntungan, Kendala dan Solusi Pembelajaran Online Selama Pandemi Covid-19: Studi Ekploratif di SMPN 3 Bae Kudus. Journal Industrial Engineering \& Management 
Research (JIEMAR), 1 (2), 1523.

Hutauruk, A. \& Sidabutar, R. (2021). Kendala Pembelajaran Daring Selama Masa Pandemi di Kalangan Mahasiswa Pendidikan Matematika: Kajian Kualitatif Deskriptif. SEPREN: Journal of Mathematics Education and Applied, 2 (1), 45-51.

Herliandry, L., Nurhasanah, Suban, M., Kuswanto, H. (2020). Pembelajaran pada Masa Pandemi Covid-19. Jurnal Teknologi Pendidikan, 22 (1), 6570.

Maharani, N., \& Kartini, K. S. (2019). Penggunaan Google Classroom Sebagai Pengembangan Kelas Virtual dalam Keterampilan Pemecahan Masalah Topik Kinematika pada Mahasiswa Jurusan Sistem Komputer. PENDIPA Journal of Science Education, 3 (3), 167173.

Oktafia, H. Ik. (2020). Pembelajaran Daring Sebagai Upaya Study
From Home (SFH) Selama Pandemi Covid 19. Jurnal Pendidikan Administrasi Perkantoran (JPAP), 8 (3), 496503.

https://doi.org/10.1093/fampra/c my005

Oktiani, I. (2017). Kreativitas Guru dalam Meningkatkan Motivasi Belajar Peserta Didik. Jurnal Kependidikan, 5 (2), 216-232. https://doi.org/10.24090/jk.v5i2.1 939

Setiawan, A. R., Puspaningrum, M., \& Umam, K. (2019). Pembelajaran Daring di Tengah Wabah Covid19. BIODIK: Jurnal Ilmiah Pendidikan Biologi, 6 (2), 214224. https://doi.org/10.17509/t.v6i2.20 887

Umairah, P. (2020). Peningkatan Motivasi Belajar Menggunakan Google Classroom di Tengah Pandemi Covid-19 Pada Peserta Didik Kelas XI IPS 4 SMAN 1 Bangkinang Kota. Journal On Education, 2 (3), 275-285. 